\title{
The role of CD4 and CD8 T cells in human cutaneous leishmaniasis
}

\author{
Claire da Silva Santos ${ }^{1}$ and Cláudia Ida Brodskyn ${ }^{1,2,3}$ * \\ ${ }^{1}$ Centro de Pesquisas Gonçalo Moniz, Fundação Oswaldo Cruz (Fiocruz) Bahia, Salvador, Brazil \\ ${ }^{2}$ Faculdade de Medicina da Universidade Federal da Bahia, Salvador, Brazil \\ ${ }^{3}$ Instituto de Investigação em Imunologia - Instituto Nacional de Ciência e Tecnologia (iii-INCT), Salvador, Brazil
}

\section{Edited by:}

Mohammed Wael Daboul, Daboul

Medical Laboratory, Syria

\section{Reviewed by:}

Christian Bogdan,

Friedrich-Alexander-Universität

Erlangen-Nürnberg and

Universitätsklinikum Erlangen,

Germany

Mauricio Martins Rodrigues, Federal

University of São Paulo, Brazil

\section{*Correspondence:}

Claire da Silva Santos and Cláudia Ida

Brodskyn, Laboratório Integrado de

Microbiologia e Imunorregulação,

Centro de Pesquisas Gonçalo Moniz,

Rua Waldemar Falcão, 121 Candeal,

Salvador, Bahia 40295-001, Brazil

e-mail:cler_ss@hotmail.com;

brodskyn@bahia.fiocruz.br
Leishmaniasis, caused by infection with parasites of the Leishmania genus, affects millions of individuals worldwide. This disease displays distinct clinical manifestations ranging from self-healing skin lesions to severe tissue damage. The control of Leishmania infection is dependent on cellular immune mechanisms, and evidence has shown that CD4 and CD8T lymphocytes play different roles in the outcome of leishmaniasis. Although the presence of CD4T cells is important for controlling parasite growth, the results in the literature suggest that the inflammatory response elicited by these cells could contribute to the pathogenesis of lesions. However, recent studies on CD8 T lymphocytes show that these cells are mainly involved in tissue damage through cytotoxic mechanisms. In this review, we focus on the recent advances in the study of the human adaptive immunological response in the pathogenesis of tegumentary leishmaniasis.

Keywords: adaptive immunity, human adaptive immunology, cutaneous leishmaniasis, CD4 and CD8 T cells, Leishmania braziliensis, immune response
Tegumentary leishmaniasis (TL) is transmitted by sand flies and is caused by different species of Old and New World Leishmania. The disease is characterized by a wide spectrum of clinical manifestations, including self-healing skin lesions, cutaneous leishmaniasis (CL), disseminated leishmaniasis (DL), mucosal leishmaniasis (ML), and diffuse cutaneous leishmaniasis (DCL) [reviewed in Ref. (1) ]. Host-parasite interactions can lead to a series of events, culminating in the different forms of clinical manifestations. This review will address the role of adaptive immunological responses in the pathogenesis of TL.

\section{A BRIEF SUMMARY OF INNATE IMMUNE RESPONSES IN INFECTIONS CAUSED BY LEISHMANIA}

In the early events after Leishmania infection, macrophages are activated, leading to NO synthesis (2-6), ROS production, and lysosomal enzyme activation $(7,8)$, which are responsible for killing the parasite. In contrast, the alternative activation of macrophages by TGF- $\beta$ provides a favorable environment for Leishmania proliferation (9). Indeed, alternatively activated macrophages preferentially induce the arginase activity responsible for parasite replication (10). Recently, the importance of neutrophils in the first events after Leishmania infection was demonstrated. Using intravital microscopy, Peters et al. showed these cells are rapidly recruited to the infection site and are responsible for phagocytosis of the parasites (11). Furthermore, these cells undergo apoptosis, and the parasites released in this process are engulfed by macrophages, creating an anti-inflammatory environment that favors the establishment of infection. Our group also observed that Leishmania amazonensis-infected macrophages in the presence of resting apoptotic neutrophils produce TGF- $\beta$ and PGE-2, leading to parasite replication. Conversely, the presence of necrotic neutrophils induces activation in infected macrophages, with a decrease in the number of parasites phagocytosed by macrophages (12). Human neutrophils were found to be activated by $L$. amazonensis via LTB-4 production, which promotes neutrophil degranulation and the killing of parasites (13). In addition, the release of neutrophil-derived extracellular DNA-containing antimicrobial peptides is an important neutrophil function that contributes to parasite killing $(14,15)$.

Dendritic cells (DCs) are critical for the initiation of an effective immune response against Leishmania. In the murine model of Leishmania major, DC infection leads to cell activation, which upregulates costimulatory molecules, such as MHC II, CD80, and CD86, and the release of IL-12, antigen presentation and T cell priming $(16,17)$. Some reports have shown that infection with different species of Leishmania parasites does not lead to changes in the activations markers on DCs $(18,19)$. For instance, the infection of DCs by Leishmania braziliensis inhibits the up-regulation of activation markers and antigen presentation, whereas uninfected cells are able to up-regulate MHC class II and costimulatory molecules, inducing $\mathrm{T}$ cell activation (20). It was suggested that these DCs in L. braziliensis infection lead to T cell activation, with infected DCs contributing to parasite control through enhanced TNF- $\alpha$ production.

In human leishmaniasis, NK cells are found to accumulate rapidly at the inoculation site after Leishmania parasite invasion 
(21). These cells are an important source of interferon (IFN)- $\gamma$, which elicits microbicidal activity by macrophages. The protective role of NK cells in human leishmaniasis can be evidenced by the recruitment of NK cells into the lesions of DCL patients who respond to treatment $(22,23)$.

\section{IMMUNE RESPONSES MEDIATED BY CD4 T CELLS IN HUMAN CUTANEOUS LEISHMANIASIS}

The cellular immune responses in leishmaniasis have been extensively studied in mouse models, mainly using L. major infection. Susceptible mice $(\mathrm{BALB} / \mathrm{c})$ develop progressive lesions, with a predominance of the Th2 response, leading to the production of anti-inflammatory cytokines, such as IL-4, IL-5, and IL-13. Resistant mice infected by L. major display small lesions with few parasites and a predominance of IFN- $\gamma$, TNF- $\alpha$, and IL-2 cytokines, characteristic of a Th1 response. These latter cytokines activate leishmanicidal mechanisms in infected macrophages, with high ROS and NO production, leading to parasite killing (24).

In human beings, the immune response has an essential role in pathogenesis, and it is not possible to observe Th1 and Th2 polarization. The cytokine profiles produced by $\mathrm{T}$ cells are associated with the healing process $(25-27)$ or with the development of disease (28-30), as well as protective mechanisms (31). The unresponsive pole of the disease observed in DCL is characterized by the high production of anti-inflammatory cytokines, such as IL-10, IL-4, and IL-2, but there is no IFN- $\gamma$ production upon in vitro stimulus with Leishmania antigens (28). However, in ML, the responsive pole of the disease, the cells from patients display an exacerbated immune response (32) with a positive DTH (3335). There is some evidence that the tissue destruction observed in LCL and ML is related to the immune response rather than to the parasites present in the lesions, the number of which is very low [reviewed in Ref. (1)].

Cells from ML patients stimulated in vitro with Leishmania antigens secrete higher concentrations of pro-inflammatory cytokines, such as TNF- $\alpha$ and IFN- $\gamma$, compared to cells from CL patients (32). These cytokines are also present in the lesions of ML patients (34), and TNF- $\alpha$ levels decrease following treatment. The immune response in CL patients reveals a mixture of cytokines, with the presence of anti- and pro-inflammatory cytokines in tissues. CD4 T cells are the major source of $\operatorname{IFN}-\gamma(36,37)$, and this cytokine, as well as TNF- $\alpha$, controls parasite multiplication during the early phases of Leishmania infection. Regardless, these cytokines also mediate the tissue damage (30). CD4 T cells at the site of skin lesions were found to be the key producers of IFN- $\gamma$ upon restimulation in vitro and were capable of activating macrophages for the killing of intracellular parasites. Unlike CD8 T cells, CD4 T cells were reported not to be involved in the cytolysis of infected target cells. Therefore, no correlation between CD4 T cells and lesion size/immunopathology was found (38).

In CL patients, TNF- $\alpha$ is produced by different types of cells, including lymphocytes and macrophages (16). Recently, a positive correlation between ulcer size at the time of the first evaluation and TNF- $\alpha$ levels was observed, supporting the use of TNF inhibitors combined with standard therapy to improve recovery time in CL patients with severe lesions (39). The treatment of leishmaniasis patients with pentoxifylline associated with a pentavalent antimonial decreased the recovery time in CL and ML patients, even in those who were refractory to conventional treatment $(40,41)$.

IL-10 is also produced by CL patients and is responsible for down-regulating inflammatory responses, mainly those induced by IFN- $\gamma$ (42-44). IL-10 is produced by a variety of cells, including macrophages, regulatory $\mathrm{T}$ (Treg) cells, Th1 cells, and CD8 $\mathrm{T}$ cells. The presence of Treg cells (natural and inducible) in the lesions from CL patients as well as IL-10 and TGF- $\beta$ production has already been described. These cytokines are responsible for the control of the immune response in CL patients but also for the pathology of disease, deactivating the mechanisms of macrophage killing and leading to parasite persistence $(45,46)$. A downregulation of IL-10 receptor was demonstrated in lesions from ML patients, which can partly explain the lack of IL-10 response and the absence of inflammatory process down-regulation (34).

More recently described cytokines are also observed in TL patients. IL-27, a cytokine with close structural and functional similarity to the IL-6/IL-12 family, is also expressed at high levels in the peripheral blood and tissues of ML and CL patients. Despite the induction of Th1 differentiation during the first steps of the immune response, IL-27 has been shown to promote an attenuation of inflammatory responses, improving IL-10 production by Th1 CD4 T cells (47-49). This function precludes inflammation and subsequent tissue damage in the late phase of the immune response. However, Oliveira et al. showed that the addition by IL27 of PBMCs from CL and ML patients did not enhance IL-10 production by these cells, suggesting that IL-27 did not have an effect on regulating the strong inflammatory response observed in human CL patients (50).

To better understand the pathogenesis of TL, Carvalho' group has studied SC patients, who display a positive DTH response against Leishmania antigens but do not exhibit any lesions. These patients are infected by L. braziliensis, but their immune responses are protective against the development of disease. Individuals with SC L. braziliensis infection present cellular immune responses that are less intense than those observed in CL or ML and produce significantly lower levels of IFN- $\gamma$ and TNF- $\alpha$ than CL patients (51). More recently, Novoa et al. reported a stronger Th1 response in CL patients than in SC individuals, though the levels of IL10 were higher in the latter patients than in the former patients (52). Although the mechanisms by which SC individuals control parasite growth are unknown, innate immune responses could play an important role in this control, with the participation of neutrophils, macrophages, and NK cells [reviewed in Ref. (53)].

More recently, the role of TH17 cells in the pathogenesis of TL has been discussed. Although the presence of these cells has been associated with the pathology of many autoimmune diseases, their role in leishmaniasis is not clear. The presence of Th17 cells and neutrophil recruitment are observed in the ML lesions of patients, in areas of necrosis and also with MMP-9 participation $(54,55)$. However, in CL patients, IL-17 is present in the supernatant of cells stimulated by Leishmania antigens; nonetheless, its role in the pathology of the disease is not well established (55). Therefore, different subsets of CD4 T cells not only produce cytokines responsible for the control of parasite proliferation but also contribute to the development of inflammatory responses. The lack 
of down-regulation of this inflammation could be responsible for the pathogenesis, as is observed in ML patients. However, as observed in SC patients, the balance of pro- and anti-inflammatory cytokines contributes to protection against the disease. In addition, there is recent evidence of the role played by CD8 T cells in the pathogenesis of the disease.

\section{CD8 T CELL IMMUNE RESPONSE IN LEISHMANIA sp INFECTION}

CD8 T cells provide immunity against a wide variety of pathogens, including viral, bacterial, and protozoal infections. These cells are generally considered to contribute to immunity and protection against Leishmania.

Muller et al. showed that the initial transitory depletion of CD4 T cells in mice susceptible to $L$. major infection causes them to be resistant to infection by the parasite via a mechanism that is dependent on an environment enriched by CD8 T cells (56). The authors demonstrated that CD8 T cells play an important role in protection after re-infection, producing high amounts of IFN- $\gamma$ (56). CD8 T cells from healed mice were able to transfer DTH responses to naïve recipients (57) and also displayed cytotoxic activity (58). Contradicting these findings, it was demonstrated that CD8 T cells were not essential to the primary protective response to L. majorinfected mice because $\beta 2$-microgobulin-deficient or $C d 8$-/- mice maintained their capacity to resolve the primary infection $(59,60)$. In 2002, using an intradermal model of infection with low number of parasites $(\sim 100)$, Belkaid et al. demonstrated that CD8 T cells are important for the control of primary infections in resistant mice infected by L. major (61). In this low-infection model, CD8 $\mathrm{T}$ cells producing IFN- $\gamma$ promoted the change from the early Th2 response toward a Th1 response (62).

CD8 T cells producing IFN- $\gamma$ are also important for the modulation of the CD4 $\mathrm{T}$ cell response. Although the depletion of CD8 $\mathrm{T}$ cells did not interfere with the proliferative ability of CD4 $\mathrm{T}$ cells, a reduction in the percentage of CD4 T cells producing IFN- $\gamma$ was observed, an effect that was associated with an increase in parasite load in mice, suggesting an interaction between CD4 and CD8 T cells (63). In human leishmaniasis, important roles of CD8 $\mathrm{T}$ cells in the healing process through IFN- $\gamma$ production $(25,27,64)$ and in resistance to the infection have been described (31). However, few reports have evaluated the role of these cells in the primary infection. Our group used an experimental approach called in vitro priming, in which cells from healthy volunteers were stimulated by L. amazonensis and cultured for $96 \mathrm{~h}$. We observed that CD8 T cells were the first to express activation markers and were important for Th1 activation (65). In infection by $L$. braziliensis, an increase in the number of CD8 $\mathrm{T}$ cells reactive to Leishmania antigens during the healing process was observed (66); large proportion of these cells could also be observed at the inflammatory site of the infection (67). A higher amount of CD8 T cells producing IFN- $\gamma$ was also associated with protective immunity in infection by L. major (68). However, the presence of CD8 $\mathrm{T}$ cells showing functional exhaustion has been observed in DCL patients: these cells produce a low level of IFN- $\gamma$ upon stimulation compared to CL patients (69). Therefore, these cells would be important in the development of acquired immunity to the infection.
CD8 T cells are also able to produce IL-10. Bourreau et al. analyzed PBMCs from unexposed naïve subjects and CL patients in response to Leishmania guyanensis stimulation and demonstrated that IL-10 was produced by the cells from both groups when TGF- $\beta$ was neutralized. An analysis of the phenotype of IL-10-producing cells in naïve subjects clearly showed that they are memory cells characterized as CD45RA-CD8 T cells (70) and appear to be effective during human infection.

Despite the apparent protective role of CD8 T cells following infection with the intracellular Leishmania parasite, these cells have been paradoxically linked to immunopathological responses. Our group implicated CD8 T cells in the pathogenesis of ML (71, 72). The presence of cytolytic CD8 T cells has also been demonstrated in the lesions from CL patients. Machado et al. observed the presence of CD8 $\mathrm{T}$ cells and a strong expression of a molecule associated with cytotoxic activity (TIA-1) in the inflammatory site of infection (73). Moreover, Faria et al. showed the recruitment of CD8 T cells expressing granzyme A to lesions of CL patients, and the expression of this protease was positively correlated with lesion progression in these patients (74). Our group found similar results, showing the recruitment of CD8 T cells to lesion sites in CL patients. These cells expressed granzyme B and CD107a and were positively correlated with the necrosis intensity and lesion size observed in these patients (38). More recently, Novais et al. showed that disease progression and metastasis in L. braziliensis-infected mice were directly associated with the presence of CD8 T cells. The authors demonstrated that perforin-expressing CD8 $\mathrm{T}$ cells were required to mediate immunopathology and that this was independent of the parasite burden (75). In human CL caused by L. major and Leishmania mexicana, granzyme B activity was also associated with a good prognosis $(76,77)$. In these studies, the in vitro cytotoxicity observed in the co-culture of Leishmania infected macrophages with peripheral blood lymphocytes appeared to be mediated by granzyme B. However, the release of granzyme B does not appear to participate in the control of parasite growth $(38,75)$. Recently, Crosby et al. demonstrated the participation of bystander memory CD8 $\mathrm{T}$ cells expressing NKG2D in leishmanial lesion progression. The authors showed that mice infected previously by viral or bacterial pathogens and challenged by L. major developed significantly larger lesions, with an increased number of NKG2D-positive CD8 T cells; however, the immunopathology was not associated with any changes in the parasite burden (78). In fact, non-Leishmania-specific CD8 T cells are found within human leishmanial lesions (79). Taken together, these studies highlight the harmful role played by cytolytic CD8 T cells in contributing to tissue injury. These data are summarized in Table 1.

\section{CONCLUDING REMARKS}

Studies in the literature have shown the important role played by CD4 $\mathrm{T}$ cells in protection against human leishmaniasis by producing cytokines able to activate the macrophages that kill the parasites. However, a strong inflammatory response contributes to lesion development and the immunopathogenesis of the disease. More recently, the role displayed by CD8 T cells has been better characterized, mainly with regard to the infection caused by L. braziliensis in human beings and mice. These cells contribute to 


\section{Table 1 | Protective vs pathological function of CD8 T cells}

\section{PROTECTIVE ROLE OF CD8T CELLS}

Depletion of CD4 T cells in mice makes them resistant to infection, a mechanism dependent on CD8T cells

(56)

Transfer of CD8 T cells from healed mice is able to induce the DTH response in naïve recipients

(57)

Infection with a low number of parasites elicits a primary immune response by CD8 T cells

(61)

(62)

IFN- $\gamma$ produced by CD8 T cells promotes the change from a Th2 to a Th1 response

CD8 T cells are important in the healing process and in resistance to the infection in human beings

In vitro priming experiments with human cells show that CD8T cells produce IFN- $\gamma$ and drive Th1 differentiation

$(25,27,31,64,66)$

(65)

CD8 T cells in infection by L. mexicana and L. major are related to a good prognosis in human beings

(77)

(68)

\section{PATHOLOGICAL ROLE OF CD8T CELLS}

CD8T cells are not essential for the primary response to L. major in mice

Cytotoxic cells are associated with pathogenesis in mucosal leishmaniasis

CD8 T cells displaying cytotoxic activity are found at the inflammatory site of infection in human beings

CD8 $T$ cells express granzyme $A$ in the lesions of $C L$ patients

CD8 T cells expressing granzyme $B$ and CD107a, characteristic of CTL, are related to tissue damage in the lesions of CL patients

Disease progression and metastasis in L. braziliensis-infected mice are related to cytotoxic CD8T cells. the differentiation of Th1 responses in the early events of parasite infection, whereas they contribute to lesion development after establishment of the infection. Their presence and cytotoxic activity are directly correlated to the lesion size and the presence of necrosis. Interestingly, after cure of the disease, CD8 T cells can produce IFN $-\gamma$ and are also correlated with the healing process.

The understanding of the immunopathological mechanisms displayed by CD4 and CD8 T cells is essential for the design of new therapeutic and vaccine strategies in human TL.

\section{REFERENCES}

1. Carvalho LP, Passos S, Schriefer A, Carvalho EM. Protective and pathologic immune responses in human tegumentary leishmaniasis. Front Immunol (2012) 3:301. doi:10.3389/fimmu.2012.00301

2. Liew FY, Li Y, Millott S. Tumor necrosis factor-alpha synergizes with IFN-gamma in mediating killing of Leishmania major through the induction of nitric oxide. J Immunol (1990) 145:4306-10.

3. Green SJ, Crawford RM, Hockmeyer JT, Meltzer MS, Nacy CA. Leishmania major amastigotes initiate the L-arginine-dependent killing mechanism in IFNgamma-stimulated macrophages by induction of tumor necrosis factor-alpha. J Immunol (1990) 145:4290-7.

4. Stenger S, Donhauser N, Thüring H, Röllinghoff M, Bogdan C. Reactivation of latent leishmaniasis by inhibition of inducible nitric oxide synthase. J Exp Med (1996) 183:1501-14. doi:10.1084/jem.183.4.1501

5. Diefenbach A, Schindler H, Donhauser N, Lorenz E, Laskay T, MacMicking J, et al. Type 1 interferon (IFNalpha/beta) and type 2 nitric oxide synthase regulate the innate immune response to a protozoan parasite. Immunity (1998) 8:77-87. doi:10.1016/S1074-7613(00)80460-4

6. Murray HW, Nathan CF. Macrophage microbicidal mechanisms in vivo: reactive nitrogen versus oxygen intermediates in the killing of intracellular visceral Leishmania donovani. J Exp Med (1999) 189:741-6. doi:10.1084/jem.189.4.741

7. Channon JY, Roberts MB, Blackwell JM. A study of the differential respiratory burst activity elicited by promastigotes and amastigotes of Leishmania donovani in murine resident peritoneal macrophages. Immunology (1984) 53:345-55.

8. Passwell JH, Shor R, Smolen J, Jaffe CL. Infection of human monocytes by Leishmania results in a defective oxidative burst. Int J Exp Pathol (1994) 75:277-84.

9. Mosser DM, Zhang X. Activation of murine macrophages. Curr Protoc Immunol (2008) 14:14.2. doi:10.1002/0471142735.im1402s83

10. Wanasen N, Soong L. L-arginine metabolism and its impact on host immunity against Leishmania infection. Immunol Res (2008) 41:15-25. doi:10.1007/ s12026-007-8012-y
11. Peters NC, Egen JG, Secundino N, Debrabant A, Kimblin N, Kamhawi S, et al. In vivo imaging reveals an essential role for neutrophils in leishmaniasis transmitted by sand flies. Science (2008) 321:970-4. doi:10.1126/science.1159194

12. Afonso L, Borges VM, Cruz H, Ribeiro-Gomes FL, DosReis GA, Dutra AN, et al. Interactions with apoptotic but not with necrotic neutrophils increase parasite burden in human macrophages infected with Leishmania amazonensis. J Leukoc Biol (2008) 84:389-96. doi:10.1189/jlb.0108018

13. Tavares NM, Araújo-Santos T, Afonso L, Nogueira PM, Lopes UG, Soares RP, et al. Understanding the mechanisms controlling Leishmania amazonensis infection in vitro: the role of LTB4 derived from human neutrophils. J Infect Dis (2014) 210:656-66. doi:10.1093/infdis/jiu158

14. Guimarães-Costa AB, Nascimento MTC, Froment GS, Soares RPP, Morgado FN, Conceição-Silva F, et al. Leishmania amazonensis promastigotes induce and are killed by neutrophil extracellular traps. Proc Natl Acad Sci U. S. A (2009) 106:6748-53. doi:10.1073/pnas.0900226106

15. Abi Abdallah DS, Denkers EY. Neutrophils cast extracellular traps in response to protozoan parasites. Front Immunol (2012) 3:382. doi:10.3389/fimmu.2012. 00382

16. Antonelli LRV, Dutra WO, Almeida RP, Bacellar O, Gollob KJ. Antigen specific correlations of cellular immune responses in human leishmaniasis suggests mechanisms for immunoregulation. Clin Exp Immunol (2004) 136:341-8. doi:10.1111/j.1365-2249.2004.02426.x

17. Von Stebut E, Belkaid Y, Jakob T, Sacks DL, Udey MC. Uptake of Leishmania major amastigotes results in activation and interleukin 12 release from murine skin-derived dendritic cells: implications for the initiation of anti-Leishmania immunity. J Exp Med (1998) 188:1547-52. doi:10.1084/jem.188.8.1547

18. De Trez C, Brait M, Leo O, Aebischer T, Torrentera FA, Carlier Y, et al. Myd88dependent in vivo maturation of splenic dendritic cells induced by Leishmania donovani and other Leishmania species. Infect Immun (2004) 72:824-32. doi:10.1128/IAI.72.2.824-832.2004

19. Sanabria MXH, Vargas-Inchaustegui DA, Xin L, Soong L. Role of natural killer cells in modulating dendritic cell responses to Leishmania amazonensis infection. Infect Immun (2008) 76:5100-9. doi:10.1128/IAI.00438-08

20. Carvalho LP, Pearce EJ, Scott P. Functional dichotomy of dendritic cells following interaction with Leishmania braziliensis: infected cells produce high levels of TNF-alpha, whereas bystander dendritic cells are activated to promote $\mathrm{T}$ cell responses. J Immunol (2008) 181:6473-80. doi:10.4049/jimmunol.181.9.6473

21. Bogdan C. Natural killer cells in experimental and human leishmaniasis. Front Cell Infect Microbiol (2012) 2:69. doi:10.3389/fcimb.2012.00069

22. Salaiza-Suazo N, Volkow P, Tamayo R, Moll H, Gillitzer R, Pérez-Torres A, et al. Treatment of two patients with diffuse cutaneous leishmaniasis caused by Leishmania mexicana modifies the immunohistological profile but not the disease outcome. Trop Med Int Health (1999) 4:801-11. doi:10.1046/j.1365-3156.1999. 00491.x 
23. Pereira LI, Dorta ML, Pereira AJ, Bastos RP, Oliveira MA, Pinto SA, et al. Increase of NK cells and proinflammatory monocytes are associated with the clinical improvement of diffuse cutaneous leishmaniasis after immunochemotherapy with BCG/Leishmania antigens. Am J Trop Med Hyg (2009) 81(3):378-83.

24. Kaye P, Scott P. Leishmaniasis: complexity at the host-pathogen interface. Nat Rev Microbiol (2011) 9:604-15. doi:10.1038/nrmicro2608

25. Coutinho SG, Da-Cruz AM, Bertho AL, Santiago MA, De-Luca P. Immunologic patterns associated with cure in human American cutaneous leishmaniasis. Braz J Med Biol Res (1998) 31:139-42. doi:10.1590/S0100-879X1998000100019

26. Coutinho SG, Oliveira MP, Da-Cruz AM, De Luca PM, Mendonça SC, Bertho $\mathrm{AL}$, et al. T-cell responsiveness of American cutaneous leishmaniasis patients to purified Leishmania pifanoi amastigote antigens and Leishmania braziliensis promastigote antigens: immunologic patterns associated with cure. Exp Parasitol (1996) 84:144-55. doi:10.1006/expr.1996.0100

27. Da-Cruz AM, Conceição-Silva F, Bertho AL, Coutinho SG. Leishmania-reactive CD4+ and CD8+ T cells associated with cure of human cutaneous leishmaniasis. Infect Immun (1994) 62:2614-8.

28. Bomfim G, Nascimento C, Costa J, Carvalho EM, Barral-Netto M, Barral A. Variation of cytokine patterns related to therapeutic response in diffuse cutaneous leishmaniasis. Exp Parasitol (1996) 84:188-94. doi:10.1006/expr.1996.0104

29. Carvalho EM, Johnson WD, Barreto E, Marsden PD, Costa JL, Reed S, et al. Cell mediated immunity in American cutaneous and mucosal leishmaniasis. J Immunol (1985) 135:4144-8.

30. Ribeiro-de-Jesus A, Almeida RP, Lessa H, Bacellar O, Carvalho EM. Cytokine profile and pathology in human leishmaniasis. Braz J Med Biol Res (1998) 31:143-8. doi:10.1590/S0100-879X1998000100020

31. Mendonca SC, De Luca PM, Mayrink W, Restom TG, Conceicao-Silva F, DaCruz AM, et al. Characterization of human T lymphocyte-mediated immune responses induced by a vaccine against American tegumentary leishmaniasis. Am J Trop Med Hyg (1995) 53:195-201.

32. Bacellar O, Lessa H, Schriefer A, Machado P, Ribeiro de Jesus A, Dutra WO, et al. Up-regulation of Th1-type responses in mucosal leishmaniasis patients. Infect Immun (2002) 70:6734-40. doi:10.1128/IAI.70.12.6734-6740.2002

33. Pirmez C, Yamamura M, Uyemura K, Paes-Oliveira M, Conceição-Silva F, Modlin RL. Cytokine patterns in the pathogenesis of human leishmaniasis. J Clin Invest (1993) 91:1390-5. doi:10.1172/JCI116341

34. Faria DR, Gollob KJ, Barbosa J, Schriefer A, Machado PRL, Lessa H, et al. Decreased in situ expression of interleukin-10 receptor is correlated with the exacerbated inflammatory and cytotoxic responses observed in mucosal leishmaniasis. Infect Immun (2005) 73(12):7853-9. doi:10.1128/IAI.73.12.78537859.2005

35. Convit J, Ulrich M, Fernández CT, Tapia FJ, Cáceres-Dittmar G, Castés M, et al. The clinical and immunological spectrum of American cutaneous leishmaniasis. Trans R Soc Trop Med Hyg (1993) 87:444-8. doi:10.1016/0035-9203(93)90030-T

36. Bottrel RL, Dutra WO, Martins FA, Gontijo B, Carvalho E, Barral-Netto M, et al. Flow cytometric determination of cellular sources and frequencies of key cytokine-producing lymphocytes directed against recombinant LACK and soluble Leishmania antigen in human cutaneous leishmaniasis. Infect Immun (2001) 69:3232-9. doi:10.1128/IAI.69.5.3232-3239.2001

37. Antonelli LRV, Dutra WO, Almeida RP, Bacellar O, Carvalho EM, Gollob KJ. Activated inflammatory $\mathrm{T}$ cells correlate with lesion size in human cutaneous leishmaniasis. Immunol Lett (2005) 101:226-30. doi:10.1016/j.imlet.2005.06.004

38. Santos C da S, Boaventura V, Ribeiro Cardoso C, Tavares N, Lordelo MJ, et al. $\mathrm{CD} 8(+)$ granzyme $\mathrm{B}(+)$-mediated tissue injury vs. $\mathrm{CD} 4(+) \operatorname{IFN} \gamma(+)$-mediated parasite killing in human cutaneous leishmaniasis. J Invest Dermatol (2013) 133:1533-40. doi:10.1038/jid.2013.4

39. Oliveira F, Bafica A, Rosato AB, Favali CBF, Costa JM, Cafe V, et al. Lesion size correlates with Leishmania antigen-stimulated TNF-levels in human cutaneous leishmaniasis. Am J Trop Med Hyg (2011) 85:70-3. doi:10.4269/ajtmh.2011.100680

40. Lessa HA, Machado P, Lima F, Cruz AA, Bacellar O, Guerreiro J, et al. Successful treatment of refractory mucosal leishmaniasis with pentoxifylline plus antimony. Am J Trop Med Hyg (2001) 65:87-9.

41. Báfica A, Oliveira F, Freitas LAR, Nascimento EG, Barral A. American cutaneous leishmaniasis unresponsive to antimonial drugs: successful treatment using combination of $\mathrm{N}$-methilglucamine antimoniate plus pentoxifylline. Int J Dermatol (2003) 42:203-7. doi:10.1046/j.1365-4362.2003.01868.x
42. Bourreau E, Prévot G, Gardon J, Pradinaud R, Hasagewa H, Milon G, et al. LACK-specific CD4(+) $\mathrm{T}$ cells that induce gamma interferon production in patients with localized cutaneous leishmaniasis during an early stage of infection. Infect Immun (2002) 70(6):3122-9. doi:10.1128/IAI.70.6.3122-3129.2002

43. Gaafar A, Veress B, Permin H, Kharazmi A, Theander TG, el Hassan AM. Characterization of the local and systemic immune responses in patients with cutaneous leishmaniasis due to Leishmania major. Clin Immunol (1999) 91:314-20. doi:10.1006/clim.1999.4705

44. Gomes-Silva A, de Cássia Bittar R, Dos Santos Nogueira R, Amato VS, da Silva Mattos M, Oliveira-Neto MP, et al. Can interferon-gamma and interleukin-10 balance be associated with severity of human Leishmania (Viannia) braziliensis infection? Clin Exp Immunol (2007) 149:440-4. doi:10.1111/j.1365-2249.2007. 03436.x

45. Campanelli AP, Roselino AM, Cavassani KA, Pereira MSF, Mortara RA, Brodskyn CI, et al. CD4+CD25+ T cells in skin lesions of patients with cutaneous leishmaniasis exhibit phenotypic and functional characteristics of natural regulatory T cells. J Infect Dis (2006) 193:1313-22. doi:10.1086/502980

46. Carneiro FP, De Magalhães AV, De Jesus Abreu Almeida Couto M, Bocca AL, Muniz-Junqueira MI, Ribeiro Sampaio RN. Foxp3 expression in lesions of the different clinical forms of American tegumentary leishmaniasis. Parasite Immunol (2009) 31:646-51. doi:10.1111/j.1365-3024.2009.01148.x

47. Trinchieri G. Interleukin-12 and the regulation of innate resistance and adaptive immunity. Nat Rev Immunol (2003) 3:133-46. doi:10.1038/nri1001

48. Yoshimura T, Takeda A, Hamano S, Miyazaki Y, Kinjyo I, Ishibashi T, et al. Twosided roles of IL-27: induction of Th1 differentiation on naive CD4+ T cells versus suppression of proinflammatory cytokine production including IL-23induced IL-17 on activated CD4+ T cells partially through STAT3-dependent mechanism. J Immunol (2006) 177:5377-85. doi:10.4049/jimmunol.177.8.5377

49. Murugaiyan G, Mittal A, Lopez-Diego R, Maier LM, Anderson DE, Weiner HL. IL-27 is a key regulator of IL-10 and IL-17 production by human CD4+ T cells. J Immunol (2009) 183:2435-43. doi:10.4049/jimmunol.0900568

50. Oliveira WN, Ribeiro LE, Schrieffer A, Machado P, Carvalho EM, Bacellar O. The role of inflammatory and anti-inflammatory cytokines in the pathogenesis of human tegumentary leishmaniasis. Cytokine (2014) 66:127-32. doi:10.1016/j.cyto.2013.12.016

51. Bittar RC, Nogueira RS, Vieira-Gonçalves R, Pinho-Ribeiro V, Mattos MS, Oliveira-Neto MP, et al. T-cell responses associated with resistance to Leishmania infection in individuals from endemic areas for Leishmania (viannia) braziliensis. Mem Inst Oswaldo Cruz (2007) 102:625-30. doi:10.1590/S007402762007005000069

52. Novoa R, Bacellar O, Nascimento M, Cardoso TM, Ramasawmy R, Oliveira WN, et al. IL-17 and Regulatory Cytokines (IL-10 and IL-27) in L. braziliensis Infection. Parasite Immunol (2011) 33:132-6. doi:10.1111/j.1365-3024.2010.01256.x

53. De Oliveira CI, Brodskyn CI. The immunobiology of Leishmania braziliensis infection. Front Immunol (2012) 3:145. doi:10.3389/fimmu.2012.00145

54. Boaventura VS, Santos CS, Cardoso CR, de Andrade J, Dos Santos WLC, Clarêncio J, et al. Human mucosal leishmaniasis: neutrophils infiltrate areas of tissue damage that express high levels of Th17-related cytokines. Eur J Immunol (2010) 40:2830-6. doi:10.1002/eji.200940115

55. Bacellar O, Faria D, Nascimento M, Cardoso TM, Gollob KJ, Dutra WO, et al. Interleukin 17 production among patients with American cutaneous leishmaniasis. J Infect Dis (2009) 200:75-8. doi:10.1086/599380

56. Müller I, Pedrazzini T, Kropf P, Louis J, Milon G. Establishment of resistance to Leishmania major infection in susceptible $\mathrm{BALB} / \mathrm{c}$ mice requires parasite-specific CD8+ T cells. Int Immunol (1991) 3:587-97. doi:10.1093/ intimm/3.6.587

57. Müller I, Kropf P, Louis JA, Milon G. Expansion of gamma interferon-producing CD8+ T cells following secondary infection of mice immune to Leishmania major. Infect Immun (1994) 62:2575-81.

58. Da Conceição-Silva F, Perlaza BL, Louis JA, Romero P. Leishmania major infection in mice primes for specific major histocompatibility complex class Irestricted CD8+ cytotoxic T cell responses. Eur J Immunol (1994) 24:2813-7. doi:10.1002/eji.1830241135

59. Wang ZE, Reiner SL, Hatam F, Heinzel FP, Bouvier J, Turck CW, et al. Targeted activation of CD8 cells and infection of beta 2-microglobulin-deficient mice fail to confirm a primary protective role for CD8 cells in experimental leishmaniasis. J Immunol (1993) 151:2077-86. 
60. Huber M, Timms E, Mak TW, Röllinghoff M, Lohoff M. Effective and longlasting immunity against the parasite Leishmania major in CD8-deficient mice. Infect Immun (1998) 66:3968-70.

61. Belkaid Y, Von Stebut E, Mendez S, Lira R, Caler E, Bertholet S, et al. CD8+ T cells are required for primary immunity in $\mathrm{C} 57 \mathrm{BL} / 6$ mice following low-dose, intradermal challenge with Leishmania major. J Immunol (2002) 168:3992-4000. doi:10.4049/jimmunol.168.8.3992

62. Uzonna JE, Joyce KL, Scott P. Low dose Leishmania major promotes a transient $\mathrm{T}$ helper cell type 2 response that is down-regulated by interferon gammaproducing CD8+ T cells. J Exp Med (2004) 199:1559-66. doi:10.1084/jem. 20040172

63. Herath S, Kropf P, Müller I. Cross-talk between CD8(+) and CD4(+) T cells in experimental cutaneous leishmaniasis: CD8(+) T cells are required for optimal IFN-gamma production by CD4(+) T cells. Parasite Immunol (2003) 25:559-67. doi:10.1111/j.0141-9838.2004.00668.x

64. Maasho K, Sanchez F, Schurr E, Hailu A, Akuffo H. Indications of the protective role of natural killer cells in human cutaneous leishmaniasis in an area of endemicity. Infect Immun (1998) 66:2698-704.

65. Pompeu MM, Brodskyn C, Teixeira MJ, Clarêncio J, Van Weyenberg J, Coelho IC, et al. Differences in gamma interferon production in vitro predict the pace of the in vivo response to Leishmania amazonensis in healthy volunteers. Infect Immun (2001) 69(12):7453-60. doi:10.1128/IAI.69.12.74537460.2001

66. Da-Cruz AM, Bittar R, Mattos M, Oliveira-Neto MP, Nogueira R, PinhoRibeiro V, et al. T-cell-mediated immune responses in patients with cutaneous or mucosal leishmaniasis: long-term evaluation after therapy. Clin Diagn Lab Immunol (2002) 9(2):251-6. doi:10.1128/CDLI.9.2.251-256.2002

67. Da-Cruz AM, Bertho AL, Oliveira-Neto MP, Coutinho SG. Flow cytometric analysis of cellular infiltrate from American tegumentary leishmaniasis lesions. Br J Dermatol (2005) 153:537-43. doi:10.1111/j.1365-2133.2005.06647.x

68. Nateghi Rostami M, Keshavarz H, Edalat R, Sarrafnejad A, Shahrestani T, Mahboudi $\mathrm{F}$, et al. CD8+ T cells as a source of IFN- $\gamma$ production in human cutaneous leishmaniasis. PLoS Negl Trop Dis (2010) 4:e845. doi:10.1371/journal. pntd.0000845

69. Hernández-Ruiz J, Salaiza-Suazo N, Carrada G, Escoto S, Ruiz-Remigio A, Rosenstein Y, et al. CD8 cells of patients with diffuse cutaneous leishmaniasis display functional exhaustion: the latter is reversed, in vitro, by TLR2 agonists. PLoS Negl Trop Dis (2010) 4:e871. doi:10.1371/journal.pntd.0000871

70. Bourreau E, Ronet C, Couppié P, Sainte-Marie D, Tacchini-Cottier F, Launois P. IL-10 producing CD8+ T cells in human infection with Leishmania guyanensis. Microbes Infect (2007) 9:1034-41. doi:10.1016/j.micinf.2007.04.009

71. Barral-Netto M, Barral A, Brodskyn C, Carvalho EM, Reed SG. Cytotoxicity in human mucosal and cutaneous leishmaniasis. Parasite Immunol (1995) 17:21-8. doi:10.1111/j.1365-3024.1995.tb00962.x
72. Brodskyn CI, Barral A, Boaventura V, Carvalho E, Barral-Netto M. Parasitedriven in vitro human lymphocyte cytotoxicity against autologous infected macrophages from mucosal leishmaniasis. J Immunol (1997) 159:4467-73.

73. Machado P, Kanitakis J, Almeida R, Chalon A, Araújo C, Carvalho EM. Evidence of in situ cytotoxicity in American cutaneous leishmaniasis. Eur J Dermatol (2002) 12:449-51.

74. Faria DR, Souza PE, Durães FV, Carvalho EM, Gollob KJ, Machado PR, et al. Recruitment of CD8(+) T cells expressing granzyme A is associated with lesion progression in human cutaneous leishmaniasis. Parasite Immunol (2009) 31:432-9. doi:10.1111/j.1365-3024.2009.01125.x

75. Novais FO, Carvalho LP, Graff JW, Beiting DP, Ruthel G, Roos DS, et al. Cytotoxic T cells mediate pathology and metastasis in cutaneous leishmaniasis. PLoS Pathog (2013) 9:e1003504. doi:10.1371/journal.ppat.1003504

76. Hernandez-Ruiz J, Becker I. CD8 cytotoxic T cells in cutaneous leishmaniasis. Parasite Immunol (2007) 29:671-8. doi:10.1111/j.1365-3024.2007.00991.x

77. Bousoffara T, Louzir H, Ben Salah A, Dellagi K. Analysis of granzyme B activity as a surrogate marker of Leishmania-specific cell-mediated cytotoxicity in zoonotic cutaneous leishmaniasis. J Infect Dis (2004) 189:1265-73. doi:10.1086/382031

78. Crosby EJ, Goldschmidt MH, Wherry EJ, Scott P. Engagement of NKG2D on bystander memory CD8 T cells promotes increased immunopathology following Leishmania major infection. PLoS Pathog (2014) 10:e1003970. doi:10.1371/ journal.ppat.1003970

79. Da-Cruz AM, Oliveira-Neto MP, Bertho AL, Mendes-Aguiar CO, Coutinho SG. T cells specific to Leishmania and other nonrelated microbial antigens can migrate to human leishmaniasis skin lesions. J Invest Dermatol (2010) 130:1329-36. doi:10.1038/jid.2009.428

Conflict of Interest Statement: The authors declare that the research was conducted in the absence of any commercial or financial relationships that could be construed as a potential conflict of interest.

Received: 20 May 2014; accepted: 13 September 2014; published online: 29 September 2014.

Citation: da Silva Santos C and Brodskyn CI (2014) The role of CD4 and CD8 T cells in human cutaneous leishmaniasis. Front. Public Health 2:165. doi: 10.3389/fpubh.2014.00165

This article was submitted to Infectious Diseases, a section of the journal Frontiers in Public Health.

Copyright (C) 2014 da Silva Santos and Brodskyn. This is an open-access article distributed under the terms of the Creative Commons Attribution License (CC BY). The use, distribution or reproduction in other forums is permitted, provided the original author(s) orlicensor are credited and that the original publication in this journal is cited, in accordance with accepted academic practice. No use, distribution or reproduction is permitted which does not comply with these terms. 